\title{
Analysis of The Application of Scientific Methods in Learning to Academic Success Skills
}

\author{
Motlan \\ Universitas Negeri Medan, \\ North Sumatera, Indonesia \\ Jurubahasa Sinuraya \\ Universitas Negeri Medan, \\ North Sumatera, Indonesia \\ Karya Sinulingga \\ Universitas Negeri Medan, \\ North Sumatera, Indonesia
}

\begin{abstract}
This study is aimed to analysis of the application of scientific methods in learning to academic success skills. Academic success skills are based on three broad research reviews that identify the critical skills needed for students to be academically and socially successful. These key skill sets include: (a) cognitive and meta-cognitive skills such as goal setting, monitoring progress, and memory skills; (b) social skills such as interpersonal, social problem solving, listening skills, and teamwork; and (c) selfmanagement skills. In improving the skills of academic success many problems are faced. Problems can occur due to several factors including namely, concentration and memory. Scientific method which is intended to provide understanding to students in knowing, understanding various materials using a scientific approach, that information can come from anywhere, anytime, does not depend on unidirectional information. The study design was conducted on a quasi-experimental basis with 2 samples. One sample is applied scientific methods in learning that are designed along with learning tools that have been adjusted. The sample applied by the scientific method is an experimental class compared to the control class. Academic success skills are the dependent variable of the application used. The products implemented are very effective in improving the intended learning outcomes. The intended learning outcome is Academic Success Skills. This increase occurs because the design of objectives in the preparation of performance indicators is actually carried out by considering and formulating it in full. In this achievement also evidenced by a learning video that has shown every planned stage goes according to the learning device that has been prepared. In addition, improvements in each learning activity need to be constantly updated and adjusted to the characteristics of students' learning styles. Good learning management will trigger the results of good learning outcomes in accordance with planned objectives. It also proves that learning outcomes depend on the management of learning that has been prepared.
\end{abstract}

Keywords: Academic Success Skills; Scientific Methods; Learning Management.

\section{INTRODUCTION}

Academic success skills are based on humanistic philosophy informed [1], [2] by a theory of change that shows that students experience desired school outcomes when practitioners are trained to carry out strategies that foster cognitive, social, and self-management. Success skills are designed based on a review of educational psychology research literature that identifies 
critical skills such as information processing, emotional self-management, and positive social skills needed for student success.

Academic success skills are based on three broad research reviews that identify the critical skills needed for students to be academically and socially successful. These key skill sets include: (a) cognitive and meta-cognitive skills such as goal setting, monitoring progress, and memory skills; (b) social skills such as interpersonal, social problem solving, listening skills, and teamwork; and (c) self-management skills such as managing attention, motivation, and anger [1]-[4].

The statement underlying the academic success skills program is that all students need a set of cognitive, social and self-management skills that these skills can be taught. When opportunities are provided for students to learn and practice these skills in the context of caring, supportive, encouraging, self-confidence increased. Then, students become more confident to make more efforts, which leads directly to better academic and social results [5]-[8].

In improving the skills of academic success many problems are faced. Problems can occur due to several factors including namely, concentration and memory. One of the main obstacles to academic achievement is the challenge of protecting the pursuit of academic goals from unwanted distractions. There are many opportunities for undesired disturbances to hinder the achievement of academic goals. Furthermore, working memory consists of several components whose coordinated activity is responsible for temporary storage and manipulation of information.

Organizing \& Processing Information, academic challenges are more related to the lack of organization than the lack of intellectual ability. Students who are disciplined and organized will most likely be motivated. Information processing is also an important factor in academic performance. Motivation and attitude find that academic success is strongly influenced by individual differences in motivation and achievement.

Scientific method which is intended to provide understanding to students in knowing, understanding various materials using a scientific approach, that information can come from anywhere, anytime, does not depend on unidirectional information from the Teacher [9]-[11]. Therefore, the expected learning conditions created are directed to encourage students to find out from various sources through observation, and not just to be informed.

In the scientific method there are several stages/activities, namely: observe, questioning, associate, experiment, process, conclusion, and presenting [12]-[14]. Application of a scientific approach can help teachers develop more varied learning activities to facilitate students to optimize the development of their potential so that it helps optimize the problem of learning outcomes so as to increase the success of academic skills.

One of the students' successes in education is shown by their academic achievements. The effort to educate the nation means to improve the quality of human beings which basically can be realized through educational activities including the teaching and learning process in schools.

In fact, it was found that the demands of academic achievement on students were higher while the learning power was mediocre. This is what causes the level of student success in academic achievement is less as expected by the school, parents and students themselves. Conceptually consistent with Student-in-Environment school counseling theory in particular. More 
specifically, the success of academic skills is informed by a theory of change which shows that students experience desired school outcomes when trained practitioners promote strategies that foster cognitive, social, and self-management skills. Finally, theories of success change academic skills showing that these efforts can lead to increased classroom involvement, academic self-efficacy, and decreased test anxiety. In addition to the inclusion of learning and social strategies, developers of successful academic skills draw from research that is compatible with youth resilience, self-efficacy, and healthy optimism.

\section{METHODS}

The study design was conducted on a quasi-experimental basis with 2 samples. One sample is applied scientific methods in learning that are designed along with learning tools that have been adjusted. The sample applied by the scientific method is an experimental class compared to the control class. Academic success skills are the dependent variable of the application used. Data analysis using the Anova one ways test. Instrument based knowledge testing procedures with Bloom Revision Taxonomy level.

The preparation of the instrument is adjusted to the indicators of academic success skills to describe the level and achievement of the academic assessment of student success skills. This is intended to determine the assessment of student skills. Assessment of student skills proposed is an academic skill. The instrument was tested on students through pretest and posttest. The results of this test are analyzed through the difference test and state analysis during learning by comparing the conditions of the two samples.

\section{RESULT AND DISCUSSION}

In achieving the learning outcomes of students not only have increased learning but there are also those who have decreased and have not experienced an increase or decrease. This is a consideration for training on the ability of lecturers to teach material to fit and get optimal results.

Table 1 Homogeneity Test on the Multivariate Test

\begin{tabular}{lcccc}
\hline \multirow{2}{*}{$\begin{array}{l}\text { Source } \\
\text { Modec }\end{array}$} & $\begin{array}{c}\text { Dependent } \\
\text { Variable }\end{array}$ & Mean Square & $\mathrm{F}$ & Sig. \\
\hline Corrected & Pretest & 4509.092 & 27.078 & .000 \\
\cline { 2 - 5 } Intercept & Posttest & 5808.247 & 27.814 & .000 \\
\cline { 2 - 5 } & Pretest & 422266.700 & 2535.807 & .000 \\
\hline Kelas & Posttest & 582374.831 & 2788.855 & .000 \\
\cline { 2 - 5 } & Pretest & 4509.092 & 27.078 & .000 \\
\hline
\end{tabular}

Table 2 Multivariate Test Results

\begin{tabular}{llccc}
\hline Effect & & Value & $\mathrm{F}$ & Sig. \\
\hline \multirow{3}{*}{ Intercept } & $\begin{array}{l}\text { Pillai's } \\
\text { Trace }\end{array}$ & .965 & $2369.858^{\mathrm{a}}$ & .000 \\
\cline { 2 - 5 } & $\begin{array}{l}\text { Wilks' } \\
\text { Lambda }\end{array}$ & .035 & $2369.858^{\mathrm{a}}$ & .000 \\
\hline \multirow{3}{*}{ Kelas } & $\begin{array}{l}\text { Pillai's } \\
\text { Trace }\end{array}$ & .576 & 17.600 & .000 \\
\cline { 2 - 5 } & $\begin{array}{l}\text { Wilks' } \\
\text { Lambda }\end{array}$ & .453 & $20.998^{\mathrm{a}}$ & .000 \\
\hline
\end{tabular}


Based on Tables 1 and 2 it can be seen that from multivariate testing it was concluded that there were differences in learning outcomes for all classes. The difference is not only in improvement but also in the distribution of abilities and variations in students' understanding characteristics [15]-[17]. In addition, the suitability of variations between classes that are not homogeneous also affects the initial conditions that students have in achieving learning outcomes through learning designed on learning devices.

After knowing the initial data of the use of the device and the effectiveness of the use of the device, then proceed to the optimization training on teaching materials and the ability of the Model Lecturer to make adjustments to the use in the classroom [18]. Training on improving learning tools especially teaching materials is carried out during 5-10 sessions with a period of 2-3 hours per meeting. This training aims to improve and adjust teaching materials on the indicators of Academic Success Skills that are internalized in learning tools. Training and adjusting the ability of the Model Lecturer is carried out for 2 days by providing exercises and improvement suggestions to adjust the activities to the learning phase that has been designed. This adjustment was made to optimize the results of the use of learning tools and teaching materials produced.

This shows that the products implemented are very effective in improving the intended learning outcomes. The intended learning outcome is Academic Success Skills. This increase occurs because the design of objectives in the preparation of performance indicators is actually carried out by considering and formulating it in full. This cannot be achieved if the planning and design is not done as optimal as possible. Optimal planning and design is able to make the appropriate results achieved [19]-[22]. In this case, learning management has succeeded in achieving what was planned as expected.

In this achievement also evidenced by a learning video that has shown every planned stage goes according to the learning device that has been prepared. Each step carried out will indicate conformity to the achievement report achieved as the control of learning activities. Thus, the assessment of the effectiveness of use both in data and video documentation shows a very high suitability. This is a recommendation to be able to continue to be developed and applied with the control system of planning that occurs in learning [23]-[25]. This also needs to be complemented by the development of learning tools for appropriate teaching materials designed together with learning tools before learning is carried out as a preparation and anticipation of activities during the process [26]-[28].

In addition, improvements in each learning activity need to be constantly updated and adjusted to the characteristics of students' learning styles. This success is not a peak achievement but is a motivation to continue to improve learning and learning management that will be implemented to achieve the effectiveness of improving Academic Success Skills. This success is also a means in guiding and controlling the achievement of learning conducted to produce skilled and academically successful students [29]-[31]. A Good learning management will trigger the results of good learning outcomes in accordance with planned objectives. It also proves that learning outcomes depend on the management of learning that has been prepared.

\section{CONCLUSION}

The products implemented are very effective in improving the intended learning outcomes. The intended learning outcome is Academic Success Skills. This increase occurs because the design of objectives in the preparation of performance indicators is actually carried out by considering and formulating it in full. In this achievement also evidenced by a learning video that has shown every planned stage goes according to the learning device that has been 
prepared. In addition, improvements in each learning activity need to be constantly updated and adjusted to the characteristics of students' learning styles. Good learning management will trigger the results of good learning outcomes in accordance with planned objectives. It also proves that learning outcomes depend on the management of learning that has been prepared.

\section{References}

S. Cottrell, Skills for success : Personal Development and Employability. 2003.

S. A. Lynch and C. G. Simpson, "Social Skills: Laying the Foundation for Success,” Dimens. Early Child., 2010.

S. V. Burks et al., "Cognitive skills, personality, and economic preferences in collegiate success," J. Econ. Behav. Organ., 2015.

M. Gokalp, “The Effect of Students' Learning Styles to Their Academic Success,” Creat. Educ., 2013.

K. Neacy, S. A. Stern, H. M. Kim, and S. C. Dronen, "Resident perception of academic skills training and impact on academic career choice," Acad. Emerg. Med., 2000.

J. Viljaranta et al., “Children's Temperament and Academic Skill Development During First Grade: Teachers' Interaction Styles as Mediators," Child Dev., 2015.

P. Moog, A. Werner, S. Houweling, and U. Backes-Gellner, "The impact of skills, working time allocation and peer effects on the entrepreneurial intentions of scientists," J. Technol. Transf., 2015.

D. Gaul and J. Issartel, "Fine motor skill proficiency in typically developing children: On or off the maturation track?," Hum. Mov. Sci., 2016.

Y. Bengio, J. Louradour, R. Collobert, and J. Weston, "Curriculum learning," in Proceedings of the 26th International Conference On Machine Learning, ICML 2009, 2009.

J. L. Moore, C. Dickson-Deane, and K. Galyen, "E-Learning, online learning, and distance learning environments: Are they the same?," Internet High. Educ., 2011.

H. Pashler, M. McDaniel, D. Rohrer, and R. Bjork, "Learning styles concepts and evidence," Psychol. Sci. Public Interes. Suppl., 2009.

M. J. Padilla, “The science process skills," Res. Matters-to Sci. Teach., 1990.

P. Turiman, J. Omar, A. M. Daud, and K. Osman, "Fostering the 21st Century Skills through Scientific Literacy and Science Process Skills," Procedia - Soc. Behav. Sci., 2012.

M. Hodosyová, J. Útla, MonikaVanyová, P. Vnuková, and V. Lapitková, “The Development of Science Process Skills in Physics Education," Procedia - Soc. Behav. Sci., 2015.

V. Vescio, D. Ross, and A. Adams, "A review of research on the impact of professional learning communities on teaching practice and student learning," Teach. Teach. Educ., 2008.

N. M. Webb, "Student Interaction and Learning in Small Groups," Rev. Educ. Res., 1982.

B. Bell and B. Cowie, "The characteristics of formative assessment in science education," Sci. Educ., 2001.

M. Motlan, J. Sinuraya, K. Sinulingga, and S. Mihardi, "Analisis Kebutuhan Desain Perangkat Pembelajaran Berbasis Scientifics dalam Mencapai Academic Success Skill," Pros. SNFA (Seminar Nas. Fis. dan Apl., 2017.

J. Herrington and R. Oliver, "An instructional design framework for authentic learning environments," Educ. Technol. Res. Dev., 2000.

D. Learning, "Innovative Teacher Professional Development," Int. Rev. Res. Open Distance Learn., 2010.

F. Schott and N. M. Seel, "Instructional Design," in International Encyclopedia of the Social \& Behavioral Sciences: Second Edition, 2015.

J. Voogt, T. Laferrière, A. Breuleux, R. C. Itow, D. T. Hickey, and S. McKenney, "Collaborative design as a form of professional development," Instr. Sci., 2015.

A. Azapagic and R. Clift, "The application of life cycle assessment to process optimisation," Comput. Chem. Eng., 1999.

G. L. Lilien, P. D. Morrison, K. Searls, M. Sonnack, and E. Von Hippel, "Performance assessment of the lead user idea-generation process for new product development," Manage. Sci., 2002.

C. W. Species and A. Process, "COSEWIC 's Assessment Process and Criteria," Assessment, 2010. 
M. Peelo and T. Luxon, “Designing embedded courses to support international students' cultural and academic adjustment in the UK," J. Furth. High. Educ., 2007.

K. H. Liao, T. A. Le, and K. Van Nguyen, "Urban design principles for flood resilience: Learning from the ecological wisdom of living with floods in the Vietnamese Mekong Delta," Landsc. Urban Plan., 2016.

S. Hussain et al., "Implications of deep learning for the automation of design patterns organization," J. Parallel Distrib. Comput., 2018.

J. M. Shelleman, “Levers of Control: How Managers Use Innovative Control Systems to Drive Strategic Renewal.,” Acad. Manag. Perspect., 1995.

J. F. Henri, "Management control systems and strategy: A resource-based perspective," Accounting, Organ. Soc., 2006.

S. L. Boyer, D. R. Edmondson, A. B. Artis, and D. Fleming, “Self-Directed Learning: A Tool for Lifelong Learning," J. Mark. Educ., 2014. 